\title{
Sciendo
}

DOI: $10.2478 / \mathrm{aa}-2020-0007$

\section{Echoes of architectural modernism in J.G. Ballard's High-Rise}

Tereza Topolovská

Tereza Topolovská is a lecturer at the Department of English Language and Literature, Faculty of Education, Charles University, where she teaches courses on English, British and American Literature, Literary Studies and Postcolonial Literature. She received her doctoral degree from the Faculty of Arts, Charles University, Prague. Her research focuses on spatial poetics, primarily the house as a literary motif, setting and subject matter, and the conception of dwelling in modern British literature. She has participated in international conferences and published articles on Simon Mawer, E.M. Forster and Iris Murdoch in academic journals and essay collections abroad and in the Czech Republic.

\begin{abstract}
:
This article pursues the elements of architectural Modernism in James Graham Ballard's 1975 novel High-Rise (1975). The enormous tower block represents a triumph of technological and constructional progress envisioned by the pioneers of modernist architecture. However, Ballard's vision of social development within it is regressive and violent. In order to decipher the nature of the role, or lack thereof, of the tower block in the reformulation of its own social fabric, the paper studies the ways in which the narrative presents aspects analogous to the key elements of architectural modernism. Particular attention is paid to the narrative's reflections of radical and often contradictory visions of key figures of theoretical roots of modernism, such as Le Corbusier and Karel Teige. Their ambiguous stance on the core of modernism not only determines the outcome of the social experiment performed by Ballard in High-Rise, but can also be seen as deforming the building practice until today.
\end{abstract}

\section{Ballard's Spatial Poetics}

The choice of setting in High-Rise (1975) reflects its author's, James Graham Ballard's (1930-2009), preference for prototypical contemporary architectural structures as the settings of his works. He situates his fiction within enormous apartment blocks, gigantic shopping malls and complicated motorway systems, all attempting and inevitably failing to provide a smoothly functioning infrastructure. High-Rise is the last part of a trilogy concerned primarily with the nature of the human response to these environments. The previous two parts, Crash (1973) and Concrete Island (1974), both thematized other prototypical forms of the contemporary treatment of space - motorways and the complex, labyrinthine system of junctions. Reminiscent of modernist dreams of social utopia conditioned by a carefully 
designed environment, Ballard's constructions embody the futuristic aspirations of their creators and users alike. However, Ballard's visions tend mainly to be socially regressive and violent. The sterile, phobic milieus develop the theme of the relation between the human subject and contemporary architecture, implying the impression of redundancy and insignificance of the former in view of the inappropriately gigantic size and hostility of the latter. The man-made landscape of his works seems to be "an environment built, not for man, but for man's absence" (Ballard, 2016, p. 28).

Ballard's focus on space and place echoes one of the chief preoccupations of contemporary literary theory. The work of Martin Heidegger and Gaston Bachelard helped to situate place at the centre of phenomenological as well as psychoanalytic inquiry. This approach has influenced the emergence of a variety of disciplines, with some of them not necessarily literary ones, such as humanistic geography. In accordance with the earlier philosophical postulates, authors such as Yi Fu Tuan have been highlighting the position of place as the foundation stone of human experience. In his Place, an Introduction (2015), Tim Cresswell mentions the emergence of critical human geographers, whose approach was affected by Marxism, feminism and cultural studies, highlighting the social construction of places and mainly the role of unequal power relations within the process. According to Creswell, the most recent development of thinking about places seems to favour a syncretic approach which views place as a combination of "parts that links the inside of the place to what lies beyond" (Creswell, 2015, 55). From the literary point of view, this tendency has been illustrated by the practice of "place-writing" which uses story-telling to bring a place (mainly real-life ones) into existence in all its complexity, combining a descriptive, a social constructionist and a phenomenological approach to a real place. Literary theory adopted relevant parts of this complex, syncretic approach, and highlights the number of creative strategies to present places as complexes consisting of a number of varied elements illustrated and often accompanied by narratives. The role of narratives in the construction of the meaning of a place is mirrored by a parallel tendency to study the textual representation or rendering of places and spaces from the point of view of their descriptive, social constructionist and phenomenological dimension. Ballard's tendency to weave his narratives around emblematic places of contemporary existence seems to call for a similar kind of study combining a number of different approaches.

\section{Dualities}


Ballard's narratives frequently perform social experiments in the phobic settings typical of contemporary existence. Philip Tew branded this aspect as "the mythopoeic element" (Tew, 2004, p.133) and described it as a tendency to retain a certain degree of analogy to reality typical of the post-war British novel. Ballard's ability to hold the world at a critical distance and depart gradually, but insistently, from the ordinary, results in him being classified amongst the "more self-consciously literary authors such as Martin Amis, Pat Barker, William Boyd and Alex Garland" (Higson, 2006, p. 59). Ballard's narratives are viewed as occupying the zone between practical and theoretical possibility. In High-Rise, the enormous tower block houses 2,000 tenants within each of its five towers in a peculiar type of traditional human habitat, a village, albeit, a vertical one. The towers are erected with a view over the City of London and in a way that each one can be seen from the others; and yet, even as events take a violent turn, no authorities are called to intervene. The impression of isolation of the enormous building slowly grows into a complete alienation of its tenants from reality. The laws of gravity, temporal constraints, and the sense of habitual social order suspended, the narrative's qualities verge on the mythical.

The building is said to challenge the sun, to colonize the sky, thus boxing in its inhabitants and effectively leaving them "abandoned" (Ballard, 2016, p. 1) in the sky together with their flats and facilities. The megalomaniac streak in the size of the structure might be seen as a factor contributing to the spectacular collapse of its functioning within the limits of civilized behaviour. The Babylonian theme coincides with the premise of the quasi-mythical nature of the subject matter. Another element which anchors the narrative within the sphere of the mythical is the archetypical conception of the protagonists. The prototypical architect, Anthony Royal, lives at the top of the building. He presides over the struggle of the superior parts of the development to retain the exclusivity of their position, which is translated into an effort to maintain and dominate the uppermost parts of the building. Royal frequently considers the concrete landscape of and around the building as comparable to a "fallen angel" (Ballard, 2016, p. 13) "looking down at the sky, rather than up at it" (Ballard, 2016, p. 5) as if to echo the biblical motif. Another protagonist, Richard Wilder, embodies the heroic element. His ascent is a monumentally heroic attempt at conquering the structure, whose order he rebels against. His effort also symbolizes the natural tendency towards upward social mobility. Initially an outsider living in an apartment on the second floor, he sets his hyperbolic physicality on a quest for a more appropriate position within the hierarchy, his efforts emulating the trajectory of a mythical journey. He succeeds and, eventually, he even manages to kill Royal. The main character, Dr Robert Laing, does not play the part of a leader 
or a hero, but rather an observer keen on survival, withdrawn and knowing, yet unable and unwilling to revolutionize the established status quo. As the story comes to an end, he continues with his work at the medical school and at the same time founds an incestuous commune which comprises his former lover and his sister.

Ballard's fusion of opposing extremities, mainly realistic and mythical elements, seeps into other aspects of High-Rise, such as the blending of futuristic architectural design and backward social development. The traditional aspects involve both the structural elements of the narrative and the subject matter. The mythical quality of some aspects of the story, such as the conception of the protagonists and both the Babylonian theme and the theme of a voyage is merged with a setting distinctively reminiscent of contemporary architectural development.

\section{High-Rise as a reflection of contemporary architectural development}

Ballard situates the plot within a square-mile of brownfield land in the London Docklands area along the north bank of the river. The development project is two miles away from the City. David Spurr, the author of Architecture and Modern Literature, states that it is "precisely the site where in the 1980s the London Dockland Corporation would build the massive high-rise business and residential complex known as Canary Wharf" (Spurr, 2012, pp. 226-227). Ballard thematizes the disillusionment which stemmed from the negative contemporary perception of high-rises, whose epitome was the Trellick Tower in North Kensington designed by Ernö Goldfinger, a keen proponent of Le Corbusier's concept of urban space. Tower blocks should have presented a solution to the post-war housing crisis, providing decent-sized, hygienic flats. The concentration of people and especially lack of adequate maintenance and supervision from the councils which owned the high-rises resulted in the buildings becoming synonymous with social problems. The unmonitored shared spaces became frequent targets of vandalism. The tenants fell victim to both minor and more serious offences. Similarly to High-Rise, the movement around the building depended on elevators and staircases, with both of these means frequently blocked, vandalized, or destroyed, resulting in frequent conflicts ranging from bickering to physical assaults. The situation, nevertheless, never reached the point of total anarchy as presented in High-Rise.

The narrative purposefully digresses from reality due to Ballard's insistence on the upper-middle social class of his tenants. The social standing of the fictitious tenants of HighRise enables the author to inspect the zone between practical and theoretical possibilities with relative freedom and less reductive political implications. The relative social homogeneity of 
the tower's populace does not prevent further stratification. The strict division of the tower block is instead based on the level where the apartments are situated. Attempts at literal or metaphorical trespassing are seen as a trigger for aggressive social restructuring. Superior sections' arrogant, hostile response to the demands of the lower strata results in spitefulness, which evolves into downright guerrilla war.

The majority of the real-life inhabitants of high-rises were originally of lower social status. High-rises were the post-war Britain's version of social housing. Today's situation partially mirrors the past both in terms of the city council's intolerable negligence of the state of the structures and in terms of the social standing of the tenants. For example, buildings such as Trellick Tower became highly fashionable rarities, privatized and gentrified without exception. On the other hand, there are also gigantic council estates, often involving high-rise apartment towers, which face gradual disintegration and eventual demolition or complete redevelopment, since they occupy much sought-after space for commercial housing development. The notorious Aylesbury estate in south-east London housing 2,700 flats and, at its peak, somewhere between 7,000 to 10,000 residents, is now falling apart devoid of any support from the local council. Gradual disintegration is followed by the demolition of the blocks and their replacement with a "more attractive, more mixed, less isolated settlement of almost 4,000 dwellings - 50\% more than on the original estate" (Beckett, 2016). This tactic, presumably part of a New Labour scheme, which relies on a mixture of private and public means in order to achieve some form of social justice, is almost in all cases similar to Aylesbury - tainted by the fact that only a limited number of flats will be social-housing ones. In the case of Aylesbury, less than half of the original number of flats are for social rent. A number of politicians, including Tony Blair and David Cameron, repeatedly generalized about council estates and supported the notion of their social exclusion by saying of them "There are estates where the biggest employer is the drugs industry" and referring to their tenants as "the forgotten people" (Blair as quoted in Beckett, 2016). David Cameron claimed that the housing estate issue "epitomises both the scale of the challenge we face and the nature of state failure over decades" and that some housing estates were "actually entrenching poverty" (Cameron as quoted in Elvey, 2016), with hundreds of them in desperate need of either bulldozing or redevelopment. As Andy Beckett continues in his 2016 article "The fall and rise of the council estate", published in The Guardian, rehousing of the original tenants of flats built as part of the welfare-state social contract opens up a debate about gentrification and social cleansing of British cities. 
Apart from the state-assisted disintegration of sprawling council estates and social stigma the often stereotyped inhabitants of social-rent flats have to face, the estates are nowadays haunted by other, immeasurably more serious malpractices involved in the management of the estates. The Grenfell Tower disaster, which took place in June 2017 in North Kensington, London, saw a severe fire spread quickly in a high-rise social-housing building, killing 72 people. The first phase of the public inquiry into the disaster held in 2018 heard an appalling number of cases of disastrous negligence: the new cladding of the building was highly combustible (Booth 2018) and 16 council inspections failed to prevent its deployment on the building (among many other, where it is still installed) (Booth, 2018). Fire warnings had been issued months before the blaze without any effect (Booth, 2018), and the tower's smoke ventilation systems had failed days before the blaze (Booth, 2018). The tower was actually transformed into "a death trap" (Bowcott). The chief executive of the Royal Borough of Kensington and Chelsea claimed that "the council had been behaving 'like a property developer masquerading as a local authority"' (Booth, 2018), rushing the tempo of construction works, thus putting the lives of the tenants at risk. The level of mistrust and frustration of the inhabitants has been sadly deepened by the council's pressure on traumatized survivors' to rush them into rehousing and presenting them with multiple offers of flats situated in other high-rise buildings.

Similarly to the ambiguous stance presented in Ballard's narrative, the current standing of the high-rise incarnates the dreams as well as nightmares of contemporary society. The pendulum of public opinion swings between the present popularity of brutalist architecture and its aesthetic and the universal admiration and status of high-rise living, and the general distrust of the impractical, maintenance-averse architectural structures.

\section{High-Rise within the modernist landscape}

"By the way, isn't modern architecture, an architecture that lays claim to the revolutionary concept of constructivism and the functionalism of a general plan, nothing other than a utopia transformed into science, and science becoming reality in return?” (Teige, 2002, p. $6)$.

"The new artist does not imitate, he creates. He does not describe, he designs. What does he design? New values for life and life is not only materialistic, as romanticists of utility 
try to present it, but is spiritual as well”. (Theo van Doesburg as quoted in Benton, 2007, p. 149)

In spite of the high-rise replicating traditional capitalist social stratification, the building is modelled as a symbol of the liberal aspirations of contemporary architecture. Ballard's insistence on the vital role of technology in the conception and functioning of the tower block reflects the high-tech movement in architecture, while the masses of concrete to be found in the building and outside of it point towards architectural brutalism. ${ }^{1}$ Developing mainly in the 1960s and 1970s, both of these architectural movements applied in practice, and with growing radicalism, the postulates, often theoretical, of architectural modernism and also constructivism. The ideas behind the mammoth fictional housing project in High-Rise echo the radical and often distorted ideas of modernist avant-garde architects and urban planners. Ballard's novel thematizes the principal postulates of architectural modernism, such as the ineffable space, transparency, communal living, monumentalization of technology and engineering skills, and verticality, and at the same time develops a catastrophic scenario concerning the inability of the high-rise tenants to sustain the quasi-utopian living arrangement.

The parallel between architectural modernism and Ballard's High-Rise is mainly obvious due to the presence of a building, a part of a wider urban concept, which may be viewed as a realization of the oftentimes grandiose postulates of modernist principles. The realization of these, frequently utopian, visions mirrored their contradictory and in fact inconsistent, propositions. The thematic similarity is supported by abundant textual evidence, with the novel's protagonists' utterances often overlapping with the writings of the SwissFrench epitome of architectural modernism, Le Corbusier (1887-1965). He was, apart from being a revolutionary architect, urban planner, painter and sculptor, also a prolific author of various architectural treatises. While High-Rise's Laing brands one of the luxurious apartments an "over-priced cell" (Ballard, 2016, p. 1), Le Corbusier used the same expression while describing the Florence Charterhouse in Galluzo, which inspired his urban planning. In a letter he wrote in 1907 upon visiting the place, he stated: "I would have liked to live in one of what they called their cells. It was the solution for a unique kind of worker's housing, or rather for a terrestrial paradise" (Le Corbusier, 2006, pp. 82-83). Ballard describes the highrise as a "vertical city" (Ballard, 2016, p. 4). Le Corbusier presented the concept of the vertical city in his radical proposition for a brand new urban conception of Paris which he developed in "Plan Voisin" de Paris (1925). He realized that his calling was to re-construct 
the foundations of the metropolis. Instead of spreading horizontally, the vertical spheres of urban spaces should be colonized (Le Corbusier and Jeanneret, 1946, p. 119). Ballard's towers are also seen to be "colonising the skies" (Ballard, 2016, p. 20) and the novel's highrise is "a huge machine designed to serve, not the collective body of tenants, but the individual residents in isolation" (Ballard, 2016, p. 6). At this point, Ballard's and Le Corbusier's texts overlap in more aspects. Firstly, both Ballard and Le Corbusier emphasize the vital role of technology in architecture, comparing houses to machines: "The house is a machine for living in" (Le Corbusier, 1976, p. 10), "House-Machine" (Le Corbusier, 1976, p. 13), or airliners: “automatically piloted airliner" (Ballard, 2016, p. 45; Le Corbusier, 1976, p. 13). Secondly, both the novelist and the architect underline the structure's capability to shelter a multitude of tenants while providing the impression of solitude for individuals. ${ }^{2}$

Ballard's narrative could be seen as providing a comprehensive commentary upon contemporary architecture while simultaneously reflecting the heritage of architectural modernism. He most prominently comments on modernism's failed utopian aspirations of reshaping and re-constructing the world, whose defects it endeavoured to heal mainly by means of opened space. Anthony Vidler interprets the idea of "Ineffable Space" (Vidler, 2001, p. 8) as conceived by Le Corbusier, in Warped Space: Art, Architecture, and Anxiety in Modern Culture (2001). Vidler's monograph dissects the ways in which anxiety and phobias are reflected in either psychological or artistic space, and, therefore, it pays attention to the modernists' attempt to purge the public and private space of unnecessary obstructions. Vidler follows Le Corbusier on his visit to Greece, where the sight of the demolished Parthenon provided an overwhelming sensation of unlimited space: "the release of aesthetic emotion is a special function of space [...] a boundless depth opens up, effaces the walls, drives away contingent presences, accomplishes the miracle of ineffable space" (Vidler, 2001, p. 54). Le Corbusier's mission to revolutionize the metropolis resonated with this conception of space. He saw the main task of urban planning as abandoning the crooked, claustrophobic scenery of medieval cities. An ideal metropolis would take the form of dispersed blocks within a landscape garden, with human bustle separated from traffic routes to prevent collisions. The traditional, horizontal dimension of the cityscape would be replaced by this exaggerated verticality. The resulting space, as perceived by inhabitants, of gigantic towers would be dominant and limitless, purified of all possible psychological disruptions. Humans, liberated from the physical and mental constraints of space, would evolve into athletes, pouring their newly acquired muscular energy into the open space. 
Ballard's narrative also emphasizes the growing physical strength of the inhabitants. However, its necessity is not a symptom of the physical well-being of the tenants of the highrise, instead it conditions their survival. High-Rise thus adds an ironic twist of survival-of-thefittest to the myth advocated by Le Corbusier. In accordance with the modernist dictum, both the vast spaces within the tower block and outside it had been designed in order to endorse both the democratic spirit of freedom and unity and yet they provoke vandalism and agoraphobia. Despite its spectacular views, the height and distance from other buildings induces the tower block's overwhelming impression of isolation rather than liberation. The apartments are associated with "the gondola of a Ferris wheel permanently suspended three hundred feet above the ground" (Ballard, 2016, p. 3) indicating instability and a fragile equilibrium evoked by the physical qualities of the high-rise as well as its volatile social structure. The sense of uprootedness eventually robs the inhabitants of a sense of place, time and social constraints. They become free to behave in any way they wish.

Seen as an extreme, dystopian revisiting of modernist heritage, Ballard's narrative confronts another pivotal aspect of modernism: transparency. In order to achieve the impression of free-flowing space, it was seen as necessary to suspend or minimize the boundary between the inside and outside. Technological advancement provided building materials and methods which allowed the erection of multi-storey buildings with what seemed to be glass walls. Physical and metaphorical transparency dominated the modernist ethos, ethics and aesthetics: "reviving the late eighteenth-century myth of transparency, both social and spatial, Modernists evoked the picture of a glass city, its buildings invisible and society open" (Vidler, 2001, p. 50). Modernism cherished and employed various degrees of transparency, from the prismatic structure of The Glass Pavilion designed by Bruno Taut and built in 1914, the vast crystalline tables of glass employed within the works of Mies van der Rohe, to the interplay of varying degrees of translucence featured in Pierre Chareau's Maison de Verre (1928-32). Architectural modernism viewed physical transparency as the ultimate metaphor of an egalitarian society. The modernist conception had been pioneered by Jean Jacques Rousseau (1712-1778), whose view of general enlightenment “discovered liberties", but, at the same time, as Michel Foucault claims, it "invented the disciplines" (Foucault, 1979, p. 222). Michel Foucault elaborates on the principle of disciplines in his Discipline and Punish: The Birth of the Prison (1975). There he introduces the Panopticon - a machine whose principles are employed in the majority of contemporary institutional buildings from schools and hospitals to prisons, operating on a rudimentary and yet very efficient principle and abandoning the fundamental optical principle that to see involves being seen. The 
dissociation of the see/being seen dyad is perpetuated by means of either a single watchman or a limited number of observers placed in a position which obscures the vision of the observed. Those exposed in their positions, unable to specify the point and the length of the observation, assume constant observation and gradually internalize it. Thus, the Panopticon, originally developed by Jeremy Bentham (1748-1832), an English philosopher and social theoretician, is presented as an ideal instrument for restriction, confinement, surveillance and enforced compliance.

Inhabiting space with a glass wall typically involves the discomfort associated with the relative absence of control of any potential observation - after all, "[v]isibility is a trap" claimed Foucault (Foucault, 1979, p. 200). The concept of the Panopticon relies on an uneven distribution of power - the superior position of the observer evokes complex societal hierarchies. Once a system relies on the possibility of observation by peers, it is highly prone to collapsing, e.g. the infamous example of Ponte City Tower built in 1975, situated in Johannesburg in South Africa. Its architects copied the principle by positioning a hollow core in the centre of this enormous building, the windows of the apartments encircling the centre. The tower represented the height of luxurious and white-only residential living, but soon became a symbol of crime and poverty with the hollow centre re-purposed as a disposal chute and suicide drop. ${ }^{3}$

Despite the aspiration of Ballard's high-rise to provoke the functioning of this sort of mechanism, the neighbouring tower blocks as well as the City are viewed as belonging to "a different world, in time as well as space" (Ballard, 2016, p. 3). They are proximate enough to be seen and, unfortunately, felt too distant to witness the events in the building and they therefore do not impose a potential threat upon the privacy of the tenants of the high-rise. As far as the building itself is concerned, the only insight the inhabitants get into the lives of others is by means of their balconies. This aspect further cements the firm vertical stratification of the building project by allowing easy visual access to the balconies below and an obscured, indirect and far less comfortable view of the upper ones.

\section{High-Rise as a symbol of the ambiguous aspirations of architectural modernism}

Ballard's commentary on contemporary building practice is firmly rooted within the modernist context and comments on its ambiguous nature. In spite of the emphasis modernist architecture put on the liberating properties of its spaces, it proved to be rather constricting as far as the spatial practices of its inhabitants were concerned. The controlling tendencies of modernism did not only involve the places and their surroundings, but, seeing houses as total 
works of art, affected also residents' way of living. "The spirit of total design” (Marcus, 2014, p. 15) often resulted in imposing modernity upon a traditional, centuries-old system. ${ }^{4}$ What High-Rise illustrates is the paradoxical nature of a movement which, by means of one of its key figures, Le Corbusier, stipulated an overall change of aesthetic, cultural and architectural paradigm while still preserving the traditional social hierarchy. Seen from this perspective, Ballard's work exploring the human response to current architectural structures envisions the consequences of the tension between ancient models of living, and the totalizing, visionary, futuristic designs developed by Le Corbusier and the like. As in any other sphere of human activity, theoretical concepts trumpeted by their pioneers as the incarnation of rationalistic principles rarely proved entirely viable. Rarely does this ring truer than in the case of the grandiose, totalizing postulates of modernist architecture.

Towards a New Architecture (1927) has been regarded as one of the most influential manifestos of modern times and has established its author, Le Corbusier, as one of the prophets of the modern movement in architecture. He passionately argues for the implementation of rationalism in all spheres of life, much in the vein of the spirit of the Enlightenment. The first step, which is indispensable for the success of the movement and also the future of mankind, is to realize the "problem of the house" and conceive it as "a machine for living in" (Le Corbusier, 1976, p. 11) and thus finally accomplish technological and rationalist projects. Architecture, as a pure creation of spirit should cast away custom and then "we shall arrive at the 'House - Machine', the mass production house, healthy (and morally so too) and beautiful in the same way that the working tools and instruments which accompany our existence are beautiful" (Le Corbusier, 1976, p. 13). However, Le Corbusier's architectural and urban radicalism did not presuppose any fundamental social changes and even tried to supress them, famously claiming: "it is a question of building which is at the root of the social unrest today: architecture or revolution" (Le Corbusier, 1976, p. 14).

There are two elements whose importance has been overshadowed both by the bitterness of the aftermath of the glory days of apartment blocks as well as the overenthusiastic, uncritical treatment of Le Corbusier's genius: his humanism and the stress, owing much to Enlightenment ideology, he placed on man's natural "yearning for light" (Le Corbusier, 1999, p. 39). Le Corbusier's association with the brutalism of the materials he used, especially concrete, regarded by many as the peak of dehumanizing material, eclipsed his lifelong fascination with the physical and spiritual dimension of the human figure, which he turned into the fundamental unit of measurement: the Modulor. ${ }^{5}$ The urban projects Le Corbusier designed were direct continuations of his rationalizing, purifying abstraction of 
man into units. As Roxana Vicovanu states in her essay "Purism and Proportions," the historian and theorist Manfredo Tafuri criticized Le Corbusier's urbanistic concepts as poorquality ones. Speaking of Le Corbusier's buildings Tafuri attributed them with "the capacity to break open the monolithic rationale of urban utopias and to rearrange things within the very codes that it sought to establish. Corbusian architecture would thus set the " theater of their tensions and conflicts against the conceptual framework outlined in his urban planning and paintings" (2015: 27). Seen from this perspective, Ballard's High-Rise performs the same role of questioning and challenging the pretence of hygienic totalizing and utterly reductive architectural and urban design in view of the codes of behaviour it sought to eradicate.

The multifaceted talent of Le Corbusier, Vicovanu continues, "playing more or less deliberately with the various artistic languages at his disposal and maintaining the myth of a split personality" (Vicovanu, 2015, p. 27) faced much criticism, with the most acerbic diatribes usually directed towards his urban planning. One of the most scathing reviewers among his contemporaries was one of the most prominent figures of avant-garde modernism, Karel Teige (1900-1951). As a figure that influenced virtually every sphere of art, design, typography, architecture and urbanism, Teige was, as well as Le Corbusier, a keen proponent of perceiving the house as a machine. Teige identified the railcar kitchen as the model of a factory at the heart of a mechanized house. The connection of home and machine aroused anxiety, with the machine's reproductive and generalizing qualities merged with something fundamentally human, such as the dwelling. Teige, as an unorthodox Marxist, was eager to overcome the dualist opposition between the spiritual and the material, what is more: "there is no doubt that the Machine Modernist commitment to the destruction of the old dualist opposition of culture and society, art and the machine, is at its most unequivocal in the Marxist drive to deny the dualism of matter and spirit altogether" (Green, 2007, p. 74).

Teige, along with the majority of modernists, claimed that his work was devoted to profound social reform. Functional, hygienic and, primarily, affordable housing was one of the fundamental issues of the inter-war period. Some countries, such as Austria, Great Britain, the Scandinavian states, and The Netherlands put major effort into trying to face the necessity of re-housing thousands of inhabitants. Some of the architects, such as Teige, argued that the solution was to be found in collective housing and the abandonment of certain bourgeois practices, such as individualized, autonomous family apartments equipped with kitchens, which he methodically condemned as outdated or directly dangerous. In the opening of his famous enquiry into the realm of the contemporary housing crisis, the 1932 Minimum Dwelling, he states: "The minimum dwelling has become the central problem of modern 
architecture and the battle cry of today's architectural avant-garde" (Teige, 2002, p. 1). The work is mainly sociological in approach and the remedy it proposes - "the minimum dwelling" - is built upon the introduction of bed-sitting rooms for individuals, cohabitation of different sexes, generations and classes, and the communalization of most aspects of life, such as cooking, dining, studying, doing sports and holidaying. In his review of the 2002 English translation of the work, Petr Zusi pointed out "the fascinating quirkiness of this book: its combination of elated avant-garde utopianism, pouting Marxist orthodoxy, and pedantic technical precision" (Zusi, 2004, p. 135).

Teige did not believe that architecture can solve the housing crisis - it instead, he thought, heralds revolutionary social change. He called Le Corbusier's project of Mundaneum "a half-baked project" (1929), since he saw Le Corbusier's urban theories as resulting from his alliance with the interests of capital: "his radical technical ideas . . tamely adapted within the context of today's social and economic conditions" (Teige, 2002, p. 145). Teige accuses Le Corbusier of transforming the city into a "fortress" (Teige, 2002, p. 150) and monopolizing city centres with gigantic financial institutions, thus ruining small property owners. He mainly preaches against Le Corbusier's insistence that architecture is able to prevent social restructuring. In Teige's view, revolution should be replaced by architectural revolution. Any upheaval of established practices should be nipped in the bud by means of solving the housing question: "Social revolution is evidently not necessary and can be forestalled - by urbanism" (Teige, 2002, p. 148).

The eponymous High-Rise may be viewed as an unsuccessful attempt at crossbreeding the traditional and the modern (if not futuristic). The blending of the communal and the individual, of collective recreational and retail spaces and traditional dwellings in fully equipped and entirely autonomous apartments, eventually triggers a revolution. Contrary to Teige's naïve claims, the tenants of Ballard's high-rise first endeavour to usurp dominance over the communal, collective facilities based on their vertical categorization. Or, on the other hand, they try to eradicate the claim of inhabitants of superior floors over shared spaces. Thus, elevators, swimming pools, the school, the supermarket and the parking lot are the first sites of conflict. Later, the tenants retreat to apartments, leaving them only to go hunting for food, often fighting for access and survival with the communal spaces blocked and controlled by the strongest people.

Ballard's bleak vision of mankind succumbing to tribalistic urges never provides a clear answer to the question of whether the inhabitants are liberated by means of modern architecture and technology, or failed by its untimely decay, whether it is an ironic triumph of 
modern architecture or its crushing defeat, whether it is through their agency that the life functions of the building are jeopardized. Ballard's narrative dissects the utopian vision of the House-Machine as preached by modernism and it develops the very premise criticized by Teige: an attempt at imposing modern design upon a traditionally stratified society.

The building and its technology prove unable to confront the tribalistic behaviour of its dwellers, and likewise the tenants fail to meet the level of abstraction dictated by the building. The rising number of technological glitches and failings further exacerbates the problems. The narrative, however, never clearly reveals the culprit of the malfunctions, whether physical or metaphysical. The signs of the deterioration of the building affect the technology only; parts of the building become derelict, soiled and damaged, but the overall structure is left untouched. There are no cracks suggesting any structural weakness of the building. Its vital functions are, however, fading one by one - "the water-pressure failing as the pumps faltered, the electrical sub-stations on each floor switching themselves off, the elevators stranded in their shafts" (Ballard, 2016, p. 93).

The technological parts most prone to corruption are the elevators. These allow access to the upper floors and because of that they are the most susceptible. Their sabotage is followed by a number of failings of air-conditioning units, other elevators, garbage-disposal chutes and electrical switching systems. The true origin of the collapse of these support mechanisms is never revealed, and rising speculation only fuels the tension within the highrise. The trajectory of antagonisms is marked by both major and minor cases of vandalism litter from the upper floors tossed on the balconies of lower-floor apartments, blocking of spaces, depriving dwellers of access to their apartments, more or less serious physical attacks, scuffles and brawls. Throughout the novel the cardinal, pioneering breaches of norms occur during power cuts beginning with the drowning of an Afghan hound in a pool on the 10th floor. The sinister conclusion sees Laing observing a similar blackout in the neighbouring building: "Already torch-beams were moving about in the darkness, as the residents made their first confused attempts to discover where they were. Laing watched them contentedly, ready to welcome them to their new world" (Ballard, 2016, p. 248).

\section{Conclusion}

The stark dystopian development envisioned in High-Rise reflects both J.G. Ballard's preference for setting his works in contemporary manmade landscapes as well as his penchant for hyperbolic narrative development. Ballard's study of the effects of a high-rise on the 
individual and communal psyche may be read as a record of a hypothetical social experiment, and also as a searing topical commentary on architectural development. Erected upon the foundations of contemporary building practice, the building's impact in the novel is pushed to the extreme, much in the vein of estrangement from reality, so typical of Ballard.

In order to decipher the nature of the role, or lack thereof, of the tower block in the spectacularly violent reformulation of its own social fabric, it is necessary to address the contemporary building practice to which Ballard's narrative is a reaction. As the leading architectural movements of the 1970s, namely brutalism and high-tech, followed the paths established by architectural modernism, the study firstly analyses aspects analogous to its key constituents. These are the idea of free-flowing, undisturbed space and its beneficial effects on humans, belief in the beauty and omnipotence of technology, the merits of light connected with the proliferation of use of various transparent materials, mainly glass, experimentation with communal living, and the exaggerated verticality of the utopian cityscape envisaged by the modernists.

Apart from individual elements of modernism, High-Rise also addresses the dilemma concerned with the degree of its radicalism. The unparalleled architectural progress proposed by one of the pioneering figures of the movement, Le Corbusier, was only rarely accompanied by demands for any significant social change. The new way of building was surprisingly supposed to maintain and even protect the traditional social structure. The leading persona of the Czech artistic and architectural avant-garde, Karel Teige, conditioned abrupt building progress with a thorough and highly egalitarian reformulation of the social fabric. The propositions of both enfants terribles of modernism, Teige and Le Corbusier, proved to be utopian visions rather than viable solutions to the housing crisis despite the fact that both of them vehemently denied the highly abstract nature of their conceptions. Consequently, the buildings resulting directly from this source of inspiration, as well as their tenants, repeatedly failed to meet the level of perfection stipulated by both Le Corbusier and Teige.

High-Rise follows the realization of some of their radical propositions. Ballard seems to revel in the depiction of the disintegration of the house and the tenants' ethos alike. Beginning with minor technical glitches and innocent hostilities, the space of the high-rise gradually turns into a battlefield. Ballard's narrative never points to any culprits - the malfunctioning and disintegration are linked to technological failures of an almost metaphysical nature, but also with the nature of modern man itself.

Whether the high-rise is a smoothly operating auto-piloted mechanism or a failing attempt at a housing and technological utopia, it puts the Babylonian dreams of the greatness 
of modernist urban megastructures to rest. In both cases, Ballard's nightmarish narrative ironically thematizes Le Corbusier's slightly contemptuous comment: "In a complete and successful work there are hidden masses of implications, a veritable world which reveals itself to those it may concern, which means: to those who deserve it" (as quoted in Vidler, 2001, p. 54). From the point of view of the characters, the high-rise truly becomes "architecture designed for war" (5) rather than a crystalline tower full of daylight rearing its head "in a dazzling spectacle of grandeur, serenity and gladness" (Le Corbusier and Jeanneret, 1946, p. 119).

\section{Endnotes:}

${ }^{1}$ Le Corbusier defined the business of architecture as "to establish emotional relationships by means of raw materials" (Le Corbusier, 1976, p. 10). His insistence and consistent employment of raw materials, especially concrete was further developed by architects such as Ernö Goldfinger, Paul Rudolph, Ralph Rapson and Louis Kahn.

2 "D'une part, l'homme en colectivité de 3 million; d'autre part, l'homme tout seul rentrant chez lui dans sa cellule" (Le Corbusier and Jeanneret, 1946, p. 40).

${ }^{3}$ The building has been recently renovated and heavy security has been imposed, albeit with questionable outcomes: "The building is gentrifying once again - an almost color-coded gentrification as white people move back into the tower, mostly taking the more expensive upper apartments" (Stott, 2017).

${ }^{4}$ One of Le Corbusier's famous realizations of unité d'habitation is The Cité Radieuse in Marseille, which he called a vertical village. It houses 337 apartments, a school, a hotel, shops, offices and a gym in an 18-floor apartment block standing on concrete pillars. When Walter Benjamin commented on Le Corbusier's visionary modernist projects, he underlined their archaic nature by stating: "The 'ville contamporaine' of Le Corbusier is an old village on a major road. Except for the fact that it is now taken over by cars and airplanes that land in the middle of this village, nothing has changed" (as quoted in Vidler, 2001, p. 78).

${ }^{5}$ Most recently, the curators of the second of the two retrospectives held by Centre Pompidou in Paris in 2015 strived to underline that as the chief aspect of his legacy in an exhibition entitled $L e$ Corbusier: The Measures of Man.

\section{Works cited:}

Ballard, J. G., 2008 (1973). Crash. London: Harper Perennial.

Ballard, J. G., 2008 (1974). Concrete Island. London: Harper Perennial.

Ballard, J. G., 2016 (1975). High-Rise. London: Fourth Estate.

Beckett, A. 2016. "The fall and rise of the council estate." The Guardian, July 13, 2016.[qt. 22-5-2020]. Available at: https://www.theguardian.com/society/2016/jul/13/aylesbury-estatesouth-london-social-housing>

Benton, T. 2007. "Building Utopia." In: Wilk, Ch. (ed.). Modernism. Designing a New World. London: V\&A Publishing, pp. 148-223.

Booth, R. 2017. "Grenfell Tower: 16 council inspections failed to stop use of flammable cladding." The Guardian, June 21, 2017. [qt. 22-5-2020]. Available at: <https://www.theguardian.com/uk-news/2017/jun/21/grenfell-tower-16-council-inspectionsfailed-to-stop-use-of-flammable-cladding>

Booth, R. 2017. "World's End estate exemplifies fault lines of dramatic inequality." The Guardian, November 13, 2017. [qt. 22-5-2020]. Available at: 
$<$ https://www.theguardian.com/society/2017/nov/13/worlds-end-estate-exemplifies-fault-linesof-dramatic-inequality>

Booth, R. 2018. "Combustible materials were added to Grenfell tower cladding, inquiry hears." The Guardian, June 18, 2018. [qt. 22-5-2020]. Available at:

<https://www.theguardian.com/uk-news/2018/jun/18/fire-safety-rules-rely-solely-on-stayingput-grenfell-inquiry-ladders>

Booth, R. 2018. "Grenfell Tower borough 'behaved like a property developer'." The Guardian, June 20, 2018. [qt. 22-5-2020]. Available at: <https://www.theguardian.com/uknews/2018/jun/20/grenfell-tower-borough-behaved-like-property-developer-barry-quirk> Booth, R. 2018. "Grenfell Tower's smoke ventilation system 'failed days before fire'." The Guardian, June 5, 2018. [qt. 22-5-2020]. Available at: <https://www.theguardian.com/uknews/2018/jun/05/grenfell-towers-smoke-ventilation-system-failed-days-before-fires Bowcott, O. 2018. "Refurbishment made Grenfell Tower a death trap, inquiry hears." The Guardian, June 5, 2018. [qt. 22-5-2020]. Available at: <https://www.theguardian.com/uknews/2018/jun/05/dangerous-building-works-turned-grenfell-tower-death-trap-inquiry> Bradbury, M. 1994. The Modern British Novel. London: Penguin Books.

Busby, M. 2018. "Grenfell Fire Warnings Issued Months Before Blaze, Documents Show." The Guardian, August 8, 2018. [qt. 22-5-2020]. Available at:

https://www.theguardian.com/uk-news/2018/aug/08/grenfell-fire-warnings-issued-monthsbefore-blaze-show-documents>

Cinqualabre, O. and F. Migayrou (eds.). 2015. Le Corbusier, The Measures of Man. Editions du Centre Pompidou, Zurich: Schneidegger \&Spiess.

Cresswell, T. 2015 (2004). Place: An Introduction. Second Edition. Somerset: Wiley.

Davies, C. 2018. A New History of Modern Architecture. London: Laurence King Publishing. Dimbleby, D. 2007. How We Built Britain. London: Bloomsbury Publishing.

Davies, K. 2014. "The social housing stigma: how to fight the stereotyping of social tenants." The Guardian, June 10, 2014. [qt. 22-5-2020]. Available at:

<https://www.theguardian.com/housing-network/2014/jun/10/social-housing-stigmastereotype-tenants>

Deleuze, G. and F. Guattari. 2004 (1980). A Thousand Plateaus: Capitalism and

Schizophrenia. Trans. B. Massumi. London: Continuum International Publishing Group.

Doward, J. 2018. "Britain flouting human rights over Grenfell-style cladding." The Guardian, August 19, 2018. [qtd. 22-5-2020]. Available at: <https://www.theguardian.com/uknews/2018/aug/19/britain-flouting-human-rights-over-grenfell>

English, J. F., 2006. A Concise Companion to Contemporary British Fiction. London: Blackwell Publishing.

Elvey, S. 2016. "Bulldoze estates to protect Britain, says Cameron." The Sunday Express, January 10, 2016. [qt. 22-5-2020]. Available at:

‘ttps://www.express.co.uk/news/uk/633224/Bulldoze-estates-protect-Britain-Cameron>

Fierro, A. 2003. The Glass State: The Technology of the Spectacle, Paris, 1918 - 1998.

Cambridge: The MIT Press.

Foucault, M. 1979 (1975). Discipline and Punish: the Birth of the Prison. Transl. A.

Sheridan. New York: Random House.

Frampton, K. 1994. Modern Architecture. A Critical History. London: Thames and Hudson. Green, Ch. 2007. “The Machine.” In: Wilk, Ch. (ed.). Modernism. Designing a New World. London: V\&A Publishing, pp. 70-111.

Harries, K. 1997. The Ethical Function of Architecture. Cambridge: The MIT Press.

Harris, J. 2016. "The End of Council Housing." The Guardian, January 4, 2016. [qt. 22-52020]. Available at: ‘https://www.theguardian.com/society/2016/jan/04/end-of-councilhousing-bill-secure-tenancies-pay-to-stay> 
Head, D. 2002. Modern British Fiction, 1950 - 2000. London: Cambridge University Press. Higson, A. 2006. "Fiction and the Film Industry." In: English, J. F. (ed.). A Concise Companion to Contemporary British Fiction. London: Blackwell Publishing, pp. 58-79. Jones, S. 2010. "You're stigmatised if you live on a council estate." The Guardian, January 27, 2010. [qt. 22-5-2020]. Available at: https://www.theguardian.com/society/2010/jan/27/aylesbury-estate-london-residents> Le Corbusier. 1976 (1927). Towards a New Architecture. London: The Architectural Press. Le Corbusier. 1999 (1961). Talks with Students. New York: Princeton Architectural Press. Le Corbusier. 2006. Lettres à ses Maîtres, Lettres à Charles L'Eplattenier. Dumont, J. (ed.) Saint-Mandé: Éditions de Linteau.

Le Corbusier and P. Jeanerette. 1946. Le Corbusier et Pierre Jeanneret Oeuvre Complète 1910-1929. Boesiger, W., Stonorov, O. Zurich : Les Éditions d'Architecture Erlenbach. Le Corbusier. 1948. New World of Space, The Foundations of His Works. Institute of Contemporary Art: Boston.

Macdonald, S. P., 2007. "The Erasure of language.” In: College Composition and Communication, vol. 4, no. 58, pp. 585-625.

Marcus, G. H. 2014. Total Design. Architecture and Interiors of Iconic Modern Houses. New York: Rizolli International Publications.

Moore, R. 2016. "Housing estates: If they aren't broken...." The Guardian, January 31, 2016. [qt. 22-5-2020]. Available at:

$<$ https://www.theguardian.com/artanddesign/2016/jan/31/council-estates-if-they-arentbroken-lambeth-council-central-hill-estate-social-housing-affordable>.

Richardson, P. 2017. House of Fiction. From Pemberley to Brideshead, Great British Houses in Literature and Life. London: Unbound.

Spurr, David. 2012. Architecture and Modern Literature. Ann Arbor: University of Michigan Press.

Stott, R. 2017. “Inside Johannesburg's infamous Ponte City Tower.” Archdaily, April 11, 2017. [qt. 22-5-2020]. Available at: <https://www.archdaily.com/493877/inside-johannesburgs-infamous-ponte-city-tower/s

Teige, K. 2002 (1932). The Minimum Dwelling. Transl. E. Dluhosch. Cambridge: The MIT Press.

Teige, K. 2010 (1929). “Karel Teige's Mundaneum (1929)”. In: Modernist Architecture: A Database of Modernist Architectural Theory. Transl. L. Holovsky, E. Holovsky, L. Dolezel. [qt. 22-5-2020]. Available at: https://modernistarchitecture.wordpress.com/2010/10/27/karelteige\%E2\%80\%99s-\%E2\%80\%9Cmundaneum\%E2\%80\%9D-1929/>

Tew, P. 2004. The Contemporary British Novel. London: Continuum Publishing.

"Utopia Now: The Heritage of London's Brutalist Architecture - In Pictures." 2016. The

Guardian, April 8, 2016. [qt. 22-5-2020]. Available at:

$<$ https://www.theguardian.com/cities/gallery/2016/apr/08/brutal-utopia-modern-heritagelondon-architecture-brutalism>

Vicovanu, R. 2015. "Purism and proportions." In: Cinqualabre, O. and F. Migayrou (eds.). Le Corbusier: The Measures of Man. Zurich: Schneidegger \&Spiess, pp. 27-31.

Vidler, A. 2001 (2000). Warped space. Art, Architecture, and Anxiety in Modern Culture. Cambridge: The MIT Press.

Wilk, C. (ed.) 2007. Modernism. Designing a New World. London: V\&A Publishing. Zusi, P. 2004. "Review of The Minimum Dwelling by Karel Teige in Eric Dluhosch's Translation." In: The Slavic and East European Journal, vol. 48, pp. 135-136.

Tereza Topolovská

Department of English Language and Literature 
Faculty of Education, Charles University

Magdalény Rettigové 4

11639 Praha 1

Czech Republic

tereza.topolovska@pedf.cuni.cz 